GRASAS Y ACEITES 67 (1)

January-March 2016, e116

ISSN-L: 0017-3495

doi: http://dx.doi.org/10.3989/gya.0256151

\title{
Genotype and year variability of the chemical composition of walnut oil of Moroccan seedlings from the high Atlas Mountains
}

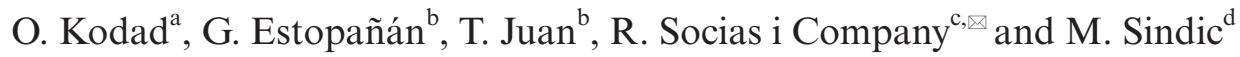 \\ ${ }^{a}$ Département d'Arboriculture. Ecole Nationale d'Agriculture de Meknès. BP S/40, Morocco \\ ${ }^{\mathrm{b}}$ Unidad de Calidad y Seguridad Alimentaria, CITA de Aragón, Av. Montañana 930, 50059 Zaragoza, Spain \\ ${ }^{\circ}$ Unidad de Fruticultura, CITA de Aragón, Av. Montañana 930, 50059 Zaragoza, Spain \\ ${ }^{\mathrm{d}}$ Unité de Technologie des Industries Agro-Alimentaires. ULg-Gembloux Agro-Bio Tech, Gembloux, Belgium \\ ${ }^{\square}$ Corresponding author: rsocias@cita-aragon.es
}

SUMMARY: Protein and oil content, fatty acid composition and tocopherol concentration were determined for two years in the kernel of ten candidate walnut selections from the high Atlas Mountains in Morocco. Considerable variation between genotypes was found for all parameters. The ranges of protein content (11.58-14.5\% of kernel dry weight, DW), oil content (54.4-67.48\% of kernel DW), oleic $(12.47-22.01 \%$ of total oil), linoleic (55.03-60.01\%), linolenic (9.3-15.87\%), palmitic (6.84-9.12\%), and stearic (1.7-2.92\%) acid percentages, $\gamma$-tocopherol $\left(188.1-230.7 \mathrm{mg} \cdot \mathrm{kg}^{-1}\right.$ of oil), $\delta$-tocopherol $\left(23.3-43.4 \mathrm{mg} \cdot \mathrm{kg}^{-1}\right)$, and $\alpha$-tocopherol (8.9-16.57 $\mathrm{mg} \cdot \mathrm{kg}^{-1}$ ) contents agreed with previous results obtained from other commercial walnut cultivars. The effect of year was significant for all the chemical components, except for oil content and palmitic acid percentage. Some genotypes showed high oil contents and consistently high values of $\gamma$-tocopherol in both years of study. The introduction of these genotypes as new cultivars by vegetative propagation may result in a an increase in quality of the walnuts from the high Atlas Mountains of Morocco, and as a seed source for forest walnut propagation in the same region.

KEYWORDS: Fatty acid profile; Genetic resources; Oil content; Protein content; Tocopherol content; Walnut

RESUMEN: Variabilidad genotípica y anual de la composición química del aceite de nuez de plantones de nogal del Alto Atlas. Se determinó durante dos años el contenido en proteína y aceite, la composición en ácidos grasos y la concentración en tocoferoles en la pepita de diez plantones de nogal seleccionados en el Alto Atlas de Marruecos, encontrándose una considerable variación entre genotipos para todos los parámetros. Los rangos del contenido en proteína (11.58-14.5\% del peso seco, PS), contenido en aceite (54.4-67.48 \% PS), porcentaje de ácido oleico (12.47-22.01\% del aceite total), linoleico (55.03-60.01\%), linolénico (9.3-15.87\%), palmítico (6.84-9.12\%), y esteárico (1.7-2.92\%), contenido en $\gamma$-tocoferol (188.1-230.7 $\mathrm{mg} \cdot \mathrm{kg}^{-1} \mathrm{de}$ aceite), $\delta$-tocoferol $\left(23.3-43.4 \mathrm{mg} \cdot \mathrm{kg}^{-1}\right)$ y $\alpha$-tocoferol $\left(8.9-16.57 \mathrm{mg} \cdot \mathrm{kg}^{-1}\right)$, coincidieron con resultados previos de otros cultivares comerciales de nogal. El efecto del año fue significativo para todos los componentes químicos, excepto para el contenido en aceite y el porcentaje de ácido palmítico. Algunos genotipos destacaron por un elevado contenido en aceite y valores consistentes de $\gamma$-tocoferol en ambos años del estudio. Estos genotipos muestran interés para su propagación vegetativa como nuevos cultivares para aumentar la calidad de las nueces del Alto Atlas, así como fuente de semillas para la propagación forestal del nogal en la misma región. 
PALABRAS CLAVE: Contenido en aceite; Contenido en proteína; Contenido en tocoferoles; Nogal; Perfil de ácidos grasos; Recursos genéticos

Citation/Cómo citar este artículo: Kodad O, Estopañán G, Juan T, Socias i Company R, Sindic M. 2016. Genotype and year variability of the chemical composition of walnut oil of Moroccan seedlings from the high Atlas Mountains. Grasas Aceites 67 (1): e116. doi: http://dx.doi.org/10.3989/gya.0256151.

Copyright: (C) 2016 CSIC. This is an open-access article distributed under the terms of the Creative Commons Attribution-Non Commercial (by-nc) Spain 3.0 Licence.

\section{INTRODUCTION}

The Persian or English walnut (Juglans regia L.) is native of the mountain ranges of Central Asia (Leslie and McGranahan, 1998). It is a traditional fruit crop in North Africa and its first introduction into the Maghreb is attributed to the Romans (Germain, 1992). Walnut trees cover an area of 7600 ha in Morocco, and are considered a forestry fruit tree by local farmers and populations. Walnut trees are found in mountainous and remote areas between 800 and $1800 \mathrm{~m}$ above sea level and in different environments (Lansari et al., 2001). The most important populations were identified in the high and medium Atlas Mountains. More than half of the trees are seedlings resulting from the prevailing way of propagation known by farmers, since grafting is unknown. As a consequence, the genetic variability of the local Moroccan walnut population is assumed to be very large (Lansari et al., 2001). Morocco, as well as other countries with forestry resources, is paying great attention in protecting seedling stands as valuable tools for biodiversity conservation, and as a source of high quality plant material. Moreover, the selection of productive and drought tolerant genotypes with high kernel quality could be essential for the conservation of walnut trees in the mountain regions of Morocco once defined and propagated by grafting, offering extra economical benefits to the farmers and local populations. The studies on the genetic diversity of the local walnut populations of Morocco are scarce, with the Moroccan germplasm being characterized by smaller fruits, more shriveled kernels, higher aborted buds and lower fruiting potential than the French germplasm, although some genotypes were selected because of their high physical quality (Lansari et al., 2001). Nevertheless, the chemical quality of the kernel of these local populations has not been approached.

Information on the composition of edible vegetable oils is required to ascertain their quality in terms of storage stability, flavor, taste, and nutrition. Such knowledge is informative for assessing the dietary intake of beneficial components of the oil (Crews et al., 2005), as well as to choose the plant source for establishing a new orchard (Malvolti et al., 2010). The high nutritive value of walnut kernels arises mainly from their high lipid content, ranging between 52 and $70 \%$, which constitutes an important caloric source (Amaral et al., 2003). Furthermore, the high lipid content in walnut kernels is relevant as a source of carbon and energy during germination and seedling growth (Chenevard et al., 1994). The major constituents of walnut oil are triglycerides, in which the fatty acid (FA) profile shows that unsaturated FA (UFA) amount to about $70 \%$ of the walnut kernel oil. Monounsaturated FA (MUFA, mainly oleic acid) and polyunsaturated FA (PUFA, mainly linoleic and $\alpha$-linolenic acids) are present in high amounts (Crews et al., 2005; Martinez et al., 2006). Their ratios are indices of the economic and nutritional value of the nut. Lower linoleic and linolenic acid contents may allow for a longer shelf life, whereas MUFAs may be more desirable because of their potential health benefits (Amaral et al., 2003). The content of UFAs and the level of lipid oxidation are the most important quality parameters in walnuts for storage stability (Jensen et al., 2001). High levels of UFAs result in oxidation products with an undesirable rancid taste.

Tocopherols are natural monophenols with antioxidant activities (Reische et al., 1998) with several homologues depending on the position and number of methyl groups. Their main biochemical function is believed to be the protection of PUFAs against peroxidation and can stabilize FAs in oil (Savage et al., 1999). The content of tocopherol homologues in nut oils is important owing to their antioxidant property and their positive nutritional effects on human metabolism. In walnuts, $\gamma$-tocopherol has been identified as the major vitamin $\mathrm{E}$ homologue, followed by $\alpha$ - and $\delta$-tocopherol (Amaral et al., 2005). High levels of $\gamma$-tocopherol may be associated with a reduction in blood cholesterol levels and in death from cardiovascular diseases. Several epidemiological and experimental studies suggest that the walnut is probably a potent chemo-preventive agent (Naito et al., 2005), and that it has an antioxidant protective function of lipid matrix for both seed germination and human consumption (Verardo et al., 2009).

The main objective of the present study was to determine the oil content, FA profile and tocopherol concentration of ten candidate walnut selections identified in the high Atlas Mountains of Morocco in order to select the genotypes of higher quality as seed sources for reforestation and as bud sources for grafting propagation as new cultivars. 


\section{MATERIALS AND METHODS}

\subsection{Plant material}

This study was carried out with 10 walnut genotypes from the Asni region in the high Atlas Mountains (center of Morocco), with wealthy genetic resources. These genotypes were selected after four years of observations based on morphological and homological traits, such as the general status of the plant (vigor, ramification, foliar density and appearance), lateral fruiting, and physical quality of the kernel, as appreciated by the local population. These genotypes were unique seedlings; therefore each genotype is a single tree. The best genotypes were marked and fruits were collected in winter during two consecutive years (2009-2010). The nuts were collected in lots of about $1 \mathrm{~kg}$ when the fruit mesocarp had fully dried and split and peduncle abscission was complete. Then the mesocarp was removed and the nuts were dried and stored at ambient temperature for three weeks. From each lot, representing each genotype, two independent samples of 30 fruits were randomly taken for analysis. After cracking, the kernels were tromped in liquid nitrogen and then ground using an electrical grinder (IKA, Staufen, Germany) to obtain a fine flour.

\subsection{Oil and protein determination}

Oil was extracted from $5 \mathrm{~g}$ of ground walnut kernel using a fat extractor Soxtec during $5 \mathrm{~h}$ and using hexane as a solvent (AOCS, 1973). The oil content was expressed as the difference in weight of the dried kernel samples before and after extraction. The protein content was obtained indirectly by determining the total $\mathrm{N}$ content obtained by the Kjeldahl method (AOAC, 1995) and multiplying by a nitrogen-protein conversion factor $(\mathrm{Kc}=6.25 ; \%$ protein $=\mathrm{Kc} * \%$ total $\mathrm{N}$ ).

\subsection{Fatty acid determination}

FAs were extracted using hexane (AOCS, 1973) and analyzed by Gas Chromatography (Series 6890, column CP 9205 WAX MS, Agilent, Santa Clara, CA, USA) as the methyl ester derivatives (FAMEs) after trans-esterification using a methanolic solution of Boron trifluoride (BF3, 10\%). These methyl esters were separated using a flame ionization detector (FID). The carrier gas was helium at a flow rate of $1 \mathrm{~mL} \cdot \mathrm{min}^{-1}$. The temperatures of the inlet and detector were held at 220 and $275^{\circ} \mathrm{C}$, respectively. The initial column temperature was $100{ }^{\circ} \mathrm{C}$ for $3 \mathrm{~min}$. The oven temperature was increased from 100 to 150 at $20^{\circ} \mathrm{C} \cdot \mathrm{min}^{-1}$ ramp rate for $1 \mathrm{~min}$, from 150 to 200 at $15^{\circ} \mathrm{C} \cdot \mathrm{min}^{-1}$ ramp rate for $3 \mathrm{~min}$, and from 200 to 240 at $3{ }^{\circ} \mathrm{C} \cdot \mathrm{min}^{-1}$ ramp rate. The temperature was kept at $240{ }^{\circ} \mathrm{C}$ for $4 \mathrm{~min}$. The injection volume was
$0.5 \mu \mathrm{L}$. The identification of individual fatty acid was achieved by comparison with the relative retention times of previous fatty acid standard injections and was expressed as percent of total fatty acids.

\subsection{Tocopherol concentration}

Tocopherol concentrations were determined in each duplicate sample as previously described (López-Ortiz et al., 2008). Samples of $0.30 \mathrm{~g}$ of walnut oil were dissolved in $2 \mathrm{~mL}$ of 1-propanol by shaking at air temperature for $3 \mathrm{~min}$. The resulting mixture was then filtered through a $0.45 \mu \mathrm{m}$ nylon syringe membrane (Phenomenex, Torrance, CA, USA) before measurement. The final extract was kept in a dark vial in a refrigerator at $2^{\circ}-4{ }^{\circ} \mathrm{C}$ until chromatographic analysis. Tocopherol homologue determinations were performed using a Kontron HPLC 360 equipped with a double piston pump (Kontron, Eching, Germany). Tocopherol homologues were detected using a Kontron 440 photodiode array detector and a Sfu 25 fluorescence detector. The chromatographic conditions finally selected for the simultaneous determination of all tocopherol homologues were as follows: $20 \mu \mathrm{L}$ of sample were injected into the chromatography column Phenomenex Luna C18 (2) $(0.5 \times 4.6 \mathrm{~mm}, 5 \mu \mathrm{m}$ particle size, $100 \AA$ pore size) while the mobile phase consisted of an acetonitrile:methanol (30:70) mixture at $30{ }^{\circ} \mathrm{C}$ at a flow rate of $1.2 \mathrm{~mL} \cdot \mathrm{min}^{-1}$ and maintained at $30{ }^{\circ} \mathrm{C}$. Tocopherol homologues were detected at $295 \mathrm{~nm}$. Peak areas were measured, and retention times were compared with standards of the three homologues (Sigma-Aldrich, Madrid, Spain), with a purity of $95 \%$ for $\alpha$-tocopherol, $96 \%$ for $\gamma$-tocopherol, and $90 \%$ for $\delta$-tocopherol. The values were confirmed by their characteristic spectra using the photodiode array detector, which also confirmed their purity. To quantify all the homologues, calibration curves were drawn. Standard linearity was verified in each case by analysis of six standards in triplicate each containing $20-200 \mathrm{mg} \cdot \mathrm{kg}^{-1}$ oil for $\alpha$-tocopherol, $0.1-8 \mathrm{mg} \cdot \mathrm{kg}^{-1}$ oil for $\gamma$-tocopherol and $0.05-5 \mathrm{mg} \cdot \mathrm{kg}^{-1}$ oil for $\delta$-tocopherol. With this method, the recovery of the three tocopherol homologues was approximately $98 \%$. Under these experimental conditions the limits of detection calculated from the residual error of the calibration curves were: $5.5 \mathrm{mg} \cdot \mathrm{kg}^{-1}$ oil for $\alpha$-tocopherol, $0.2 \mathrm{mg} \cdot \mathrm{kg}^{-1}$ oil for $\gamma$-tocopherol and $0.1 \mathrm{mg} \cdot \mathrm{kg}^{-1}$ oil for $\delta$-tocopherol. Tocopherol compositions were the mean values of three replicates $(n=3)$ from each duplicate sample and were expressed as $\mathrm{mg} \cdot \mathrm{kg}^{-1}$ oil.

\subsection{Statistical analysis}

All statistical analyses were performed with the SAS program (SAS, 2000). The analysis of variance with the PROC GLM procedure was applied to 
distinguish the effect of the genotype and the year. The additive linear model for the statistical analysis was:

$P_{i j}=\mu+g_{i}+y_{j}+(g \times y)_{i j}+\varepsilon_{i j}$

Where $P_{i j}$ is the phenotypic value of the $i$ genotype in the $j$ year, $\mu$ s overall mean, $g_{i}$ is the genotype effect, $y_{i}$ is the year effect, $(g \times y)_{i j}$ is the genotype and year interaction and $\varepsilon_{i j k}$ is the residual effect. The mean separation was done with the Duncan test at $P \leq 0.05$. The LSMEANS option of the GLM procedure was used to calculate least-square means for genotypes in each year to observe rank changes of genotypes from year to year. The coefficients of correlation between the studied variables were obtained and the Pearson's correlation coefficients were calculated following the PROC CORR procedure.

\section{RESULTS AND DISCUSSION}

\subsection{Oil and protein content}

Oil and protein contents were highly variable among genotypes (Table 1). Protein content was significantly different between years (Table 2), with a higher mean value in 2009 (Table 1). The effect of year was not significant for oil content (Table 2), although it had been significant in three other walnut cultivars (Martinez et al., 2006). Oil content ranged between 54.4 and $67.48 \%$, and protein between 11.58 and $14.5 \%$ in 2009, (Table 1), whereas in 2010 these ranges were between 55.29 and $66.25 \%$ for oil, and between $11.99 \%$ and $14 \%$ for protein (Table 1 ). Protein content agreed with previous reports (Amaral et al., 2003; Savage et al., 1999), as well as fat content, although the lowest fat value was lower than any previous report (Crews et al., 2005; Amaral et al., 2003; Martinez et al., 2006; Bada et al., 2010). The significance of the year $\times$ genotype interaction (Table 2) indicated that oil content variability was significant between years for some genotypes, as a result of the specific response by these genotypes to the environmental conditions of the year.

\subsection{Major fatty acid profile}

These oils showed a high content for PUFAs (linoleic and linolenic acids), intermediate for MUFAs (oleic acid) and low for saturated FAs (palmitic and stearic acids) as in other walnut oils (Amaral et al.,

TABLE 1. Oil and protein content and fatty acid composition of the kernels of 10 Moroccan walnut seedlings over two consecutive years

\begin{tabular}{|c|c|c|c|c|c|c|c|}
\hline Genotype & $\begin{array}{c}\text { Protein } \\
\text { content }(\% \text { of } \\
\text { kernel DW) }\end{array}$ & $\begin{array}{c}\text { Oil } \\
\text { content }(\% \text { of } \\
\text { kernel DW) }\end{array}$ & $\begin{array}{l}\text { Palmitic acid } \\
\text { ( } \% \text { of total oil } \\
\text { content) }\end{array}$ & $\begin{array}{l}\text { Stearic acid } \\
\text { ( } \% \text { of total } \\
\text { oil content })\end{array}$ & $\begin{array}{c}\text { Oleic acid } \\
\text { (\% of total oil } \\
\text { content) }\end{array}$ & $\begin{array}{c}\text { Linoleic acid } \\
\text { ( } \% \text { of total oil } \\
\text { content) }\end{array}$ & $\begin{array}{c}\text { Linolenic acid } \\
\text { (\% of total oil } \\
\text { content })\end{array}$ \\
\hline \multicolumn{8}{|c|}{ Crop year 2009} \\
\hline Asni-1 & $13.56 \pm 0.15$ & $54.04 \pm 0.41$ & $8.03 \pm 0.08$ & $2.42 \pm 0.05$ & $12.47 \pm 0.25$ & $58.47 \pm 0.33$ & $14.40 \pm 0.02$ \\
\hline Asni-2 & $14.43 \pm 0.22$ & $65.72 \pm 2.28$ & $8.53 \pm 0.13$ & $2.91 \pm 0.13$ & $15.04 \pm 0.52$ & $59.28 \pm 0.29$ & $15.49 \pm 0.12$ \\
\hline Asni-3 & $14.50 \pm 0.04$ & $58.33 \pm 3.03$ & $8.20 \pm 0.1$ & $2.48 \pm 0.16$ & $16.84 \pm 0.26$ & $55.96 \pm 0.46$ & $14.6 \pm 0.04$ \\
\hline Asni-4 & $14.43 \pm 0.04$ & $65.73 \pm 0.26$ & $7.93 \pm 0.32$ & $2.83 \pm 0.08$ & $14.30 \pm 1.4$ & $57.42 \pm 0.1$ & $13.20 \pm 0.04$ \\
\hline Asni-5 & $11.58 \pm 0.03$ & $62.51 \pm 0.36$ & $8.19 \pm 0.45$ & $2.71 \pm 0.09$ & $15.33 \pm 0.41$ & $58.02 \pm 0.96$ & $13.86 \pm 0.12$ \\
\hline Asni-6 & $12.06 \pm 0.08$ & $67.48 \pm 0.75$ & $8.06 \pm 0.12$ & $2.45 \pm 0.03$ & $16.97 \pm 0.23$ & $57.83 \pm 1.77$ & $13.48 \pm 0.09$ \\
\hline Asni-7 & $14.04 \pm 0.15$ & $60.89 \pm 0.41$ & $6.84 \pm 0.1$ & $2.72 \pm 0.13$ & $15.18 \pm 0.53$ & $59.87 \pm 0.06$ & $14.49 \pm 0.13$ \\
\hline Asni-8 & $14.43 \pm 0.29$ & $64.09 \pm 0.49$ & $7.72 \pm 0.09$ & $2.68 \pm 0.05$ & $13.53 \pm 1.16$ & $60.01 \pm 0.90$ & $15.87 \pm 0.08$ \\
\hline Asni-9 & $12.69 \pm 0.07$ & $57.56 \pm 0.73$ & $8.24 \pm 0.26$ & $2.51 \pm 0.12$ & $16.81 \pm 0.36$ & $56.27 \pm 0.42$ & $12.55 \pm 0.05$ \\
\hline Asni-10 & $14.14 \pm 0.13$ & $57.09 \pm 0.74$ & $8.23 \pm 0.23$ & $2.70 \pm 0.19$ & $17.45 \pm 0.54$ & $56.85 \pm 0.48$ & $12.38 \pm 0.16$ \\
\hline Means & $13.53 \pm 1.06$ & $61.82 \pm 4.44$ & $7.97 \pm 0.71$ & $2.63 \pm 0.21$ & $15.16 \pm 1.38$ & $58.13 \pm 1.19$ & $14.22 \pm 1.59$ \\
\hline \multicolumn{8}{|c|}{ Crop year 2010} \\
\hline Asni-1 & $12.31 \pm 0.03$ & $65.16 \pm 2.25$ & $8.28 \pm .2$ & $1.70 \pm 0.11$ & $14.40 \pm 0.26$ & $57.68 \pm 0.45$ & $13.47 \pm 0.09$ \\
\hline Asni-2 & $12.41 \pm 0.56$ & $63.15 \pm 5.19$ & $7.03 \pm 0.11$ & $2.13 \pm 0.25$ & $16.43 \pm 0.33$ & $57.17 \pm 0.97$ & $12.79 \pm 0.07$ \\
\hline Asni-3 & $12.78 \pm 0.32$ & $65.45 \pm 1.79$ & $8.44 \pm 0.25$ & $2.30 \pm 0.2$ & $14.95 \pm 0.21$ & $58.64 \pm 0.26$ & $14.07 \pm 0.07$ \\
\hline Asni-4 & $13.17 \pm 0.16$ & $64.71 \pm 2.29$ & $7.77 \pm 0.21$ & $1.80 \pm 0.09$ & $15.98 \pm 0.86$ & $57.29 \pm 0.06$ & $13.97 \pm 0.02$ \\
\hline Asni-5 & $14.01 \pm 0.03$ & $66.25 \pm 2.46$ & $9.12 \pm 0.22$ & $2.89 \pm 0.04$ & $16.14 \pm 0.34$ & $57.96 \pm 0.45$ & $13.94 \pm 0.04$ \\
\hline Asni-6 & $13.64 \pm 0.04$ & $64.59 \pm 3.55$ & $7.43 \pm 0.04$ & $2.60 \pm 0.02$ & $17.50 \pm 0.42$ & $58.01 \pm 0.75$ & $14.02 \pm 0.04$ \\
\hline Asni-7 & $12.82 \pm 0.09$ & $57.58 \pm 0.19$ & $8.40 \pm 0.18$ & $2.40 \pm 0.08$ & $19.27 \pm 0.24$ & $56.99 \pm 0.14$ & $12.43 \pm 0.09$ \\
\hline Asni-8 & $12.07 \pm 0.56$ & $57.33 \pm 2.15$ & $8.00 \pm 0.11$ & $2.50 \pm 0.14$ & $22.01 \pm 1.19$ & $55.03 \pm 1.12$ & $9.30 \pm 0.1$ \\
\hline Asni-9 & $13.87 \pm 0.33$ & $55.29 \pm 0.34$ & $7.37 \pm 0.17$ & $2.17 \pm 0.07$ & $17.62 \pm 1.12$ & $56.18 \pm 0.55$ & $12.73 \pm 0.03$ \\
\hline Asni-10 & $11.99 \pm 0.22$ & $56.86 \pm 0.57$ & $8.40 \pm 0.13$ & $2.30 \pm 0.2$ & $17.39 \pm 0.76$ & $57.06 \pm 0.42$ & $12.50 \pm 0.08$ \\
\hline Mean & $13.01 \pm 2.15$ & $61.79 \pm 5.08$ & $7.98 \pm 0.47$ & $2.28 \pm 0.36$ & $17.14 \pm 2.92$ & $57.22 \pm 2.11$ & $12.97 \pm 1.42$ \\
\hline
\end{tabular}


TABLE 2. Analysis of variance for oil content ( $\%)$, protein content $(\%)$ and fatty acid composition of Moroccan walnut seedlings

\begin{tabular}{|c|c|c|c|c|}
\hline Source of variation & df & Mean square $^{\text {a }}$ & $F$-test & $p$-value \\
\hline \multicolumn{5}{|l|}{ Protein content } \\
\hline Genotype & 9 & $3.01 * * *$ & 25.30 & $<.0001$ \\
\hline Year & 1 & $6.97 * * *$ & 58.46 & $<.0001$ \\
\hline Year $\times$ Genotype & 9 & $2.16^{* * *}$ & 18.11 & $<.0001$ \\
\hline Error & 40 & 0.12 & & \\
\hline \multicolumn{5}{|l|}{ Oil content } \\
\hline Genotype & 9 & $104.99 * * *$ & 26.11 & $<.0001$ \\
\hline Year & 1 & $1.28 \mathrm{~ns}$ & 0.32 & 0.5755 \\
\hline Year $\times$ Genotype & 9 & $10.60^{*}$ & 2.64 & 0.0169 \\
\hline Error & 40 & 4.02 & & \\
\hline \multicolumn{5}{|l|}{ Palmitic acid } \\
\hline Genotype & 9 & $0.66^{* * *}$ & 14.99 & $<.0001$ \\
\hline Year & 1 & $0.01 \mathrm{~ns}$ & 0.24 & 0.6258 \\
\hline Year $\times$ Genotype & 9 & $1.16^{* * *}$ & 26.29 & $<.0001$ \\
\hline Error & 40 & 0.04 & & \\
\hline \multicolumn{5}{|l|}{ Stearic acid } \\
\hline Genotype & 9 & $0.23 * * *$ & 11.03 & $<.0001$ \\
\hline Year & 1 & $1.96 * * *$ & 92.31 & $<.0001$ \\
\hline Year $\times$ Genotype & 9 & $0.23 * * *$ & 10.80 & $<.0001$ \\
\hline Error & 40 & 0.02 & & \\
\hline \multicolumn{5}{|l|}{ Oleic acid } \\
\hline Genotype & 9 & $14.82 * * *$ & 47.49 & $<.0001$ \\
\hline Year & 1 & $8.48 * * *$ & 27.18 & $<.0001$ \\
\hline Year $\times$ Genotype & 9 & $18.19 * * *$ & 58.28 & $<.0001$ \\
\hline Error & 40 & 0.31 & & \\
\hline \multicolumn{5}{|l|}{ Linoleic acid } \\
\hline Genotype & 9 & $3.99 * *$ & 3.70 & 0.0019 \\
\hline Year & 1 & $7.02 *$ & 6.51 & 0.0147 \\
\hline Year $\times$ Genotype & 9 & $10.10^{* * *}$ & 9.36 & $<.0001$ \\
\hline Error & 40 & 1.08 & & \\
\hline \multicolumn{5}{|l|}{ Linolenic acid } \\
\hline Genotype & 9 & $7.45^{* * *}$ & 18.56 & $<.0001$ \\
\hline Year & 1 & $33.40 * * *$ & 83.23 & $<.0001$ \\
\hline Year $\times$ Genotype & 9 & $5.55^{* * *}$ & 13.83 & $<.0001$ \\
\hline Error & 40 & 0.40 & & \\
\hline
\end{tabular}

${ }^{\mathrm{a}} \mathrm{ns}, *, * *, * * *$ : not significant or significant at $\mathrm{P}<0.05,0.01,0.001$.

2003; Savage et al., 1999). The ranges of variability for the main FAs, as shown in Table 1, were different for the two years, but similar to those already reported in other walnut oils (Amaral et al., 2003; Martinez et al., 2006; Savage et al., 1999; Bada et al., 2010). The highest values of the walnut oil were found for PUFAs: the FAs were reported as the most effective in reducing low-density-lipoprotein cholesterol in humans, although high linoleic and linolenic acid contents may result in a poor oxidative stability and shorter shelf-life of the oils (Abbey et al., 1994). However, the results of Savage et al. (1999) showed that the most unstable walnut oils, extracted from 'Esterhazy' and G139, did not have higher levels of linoleic and linolenic acids than the more stable oils from 'Vina', G120, and 'Stanley'. In addition, MUFAs were as effective as PUFAs in the reduction of low-density-lipoprotein cholesterol in humans (Mensik and Katan, 1989), and the most important MUFA in walnuts is oleic acid (Amaral et al., 2003). Therefore, the composition of the oil from these local Moroccan walnuts points out that these seedlings may be of great benefit to health and nutrition in the human diet due to their fatty acid profile.

The effect of genotype, year, and the interaction year $\times$ genotype were significant for all acids, except for the year effect for palmitic acid (Table 2). The year effect had been significant for all fatty acids, except for stearic and linoleic acids, in an Argentinian study (Martinez et al., 2006). The variability in the FA composition has been well studied in walnuts (Amaral et al., 2003; Martinez et al., 2006; Bada et al., 2010), concluding that this composition depended primarily on the genotype, with significant effects of the year, the environment, the geographical origin, and agricultural practices. In our study, the highest contents of linoleic and linolenic acids were obtained in 2009 and, conversely, that of oleic acid in 2010 (Table 1). These seedlings were not irrigated, and water stress may significantly reduce the PUFAs, especially linoleic and linolenic acids (Amaral et al., 2003). The climatic conditions during the period of fruit growth and kernel filling (May to October) were more humid and cooler in 2010 than in 2009 (data not shown). A general negative correlation of PUFAs and growing temperature had been established: PUFAs increased in the membrane as well as in the seed storage lipids with decreasing temperatures (Rennie and Tanner, 1989). Nitrogen fertilization reduced the content of oleic and linolenic acids, and increased that of linoleic acid (Verardo et al., 2013), but our seedlings were not fertilized. The negative correlation between the contents of oleic and linoleic acids $(\mathrm{r}=-0.58$ in 2009 and $\mathrm{r}=-0.77$ in 2010) and of oleic and linolenic acids ( $r=-0.68$ in 2009 and $r=-0.8$ in 2010) may explain the high value of linoleic acid in 2010. Similar correlations had been previously reported (Malvolti et al., 2010; Martinez and Maestri, 2008).

The significant year $\times$ genotype interaction for all acids (Table 2) indicated a different genotype behavior in relation to the climatic conditions, as already pointed out for other cultivars and climatic conditions (Amaral et al., 2003; Martinez et al., 2006). The genotypes Asni-6 and Asni-10 showed consistently high oleic acid contents over the two years (Table 1). In the walnut, the FA metabolism is controlled by a large number of diverse genes 
(Dandekar et al., 2005) that may react differently to stress, since a plant is a biological entity and does not behave mechanically every year. Therefore, the evaluation of the FAs over several years in the same environment is an important criterion for identification of stable genotypes to establish commercial orchards in order to produce walnuts without fluctuation in these important quality parameters.

\subsection{Tocopherol concentration}

The tocopherol profile showed that $\gamma$-tocopherol was the major homologue, followed by $\alpha$ - and $\delta$-tocopherol (Table 3), as in other genotypes (Amaral et al., 2005; Bada et al., 2010). The three tocopherol homologues showed high variability among the genotypes (Table 4), as already observed in nine cultivars, where tocopherol content was also affected by environmental factors (Amaral et al., 2005), although few significant differences were observed for the individual tocopherol homologues in the other three cultivars, where the crop year was the main variability source (Martinez et al., 2006). The mean value over the two years ranged between 188.1 and $230.7 \mathrm{mg} \cdot \mathrm{kg}^{-1}$ oil for $\gamma$-tocopherol (Table 3). This range agreed with previous results (Amaral et al., 2005), but the maximum values of the Moroccan seedlings were lower than those previously reported (Savage et al., 1999; Bada et al., 2010). The concentration of $\delta$-tocopherol ranged from 23.3 to $43.4 \mathrm{mg} \cdot \mathrm{kg}^{-1}$ oil (Table 3 ), higher than in a previous report (Amaral et al., 2005), but lower than in others (Savage et al., 1999; Bada et al., 2010). The range in variability for $\alpha$-tocopherol was between 8.9 and $16.57 \mathrm{mg} \cdot \mathrm{kg}^{-1}$ oil (Table 3), similar to that of a previous report (Amaral et al., 2005), but lower than in others (Savage et al., 1999; Bada et al., 2010). These results confirm that $\gamma$ - and $\delta$-tocopherols are the most variable homologues in walnuts.

In both years $\gamma$-tocopherol showed positive and significant correlations with oil content $(r=0.66$ in
2009 and $r=0.71$ in 2010), with linoleic acid $(r=0.81$ in 2009 and $r=0.62$ in 2010), and with linolenic acid $(r=0.79$ in 2009 and $r=0.57$ in 2010), and a negative correlation with oleic acid ( $\mathrm{r}=-0.58$ in 2009 and $\mathrm{r}=-0.68$ in 2010), agreeing with previous studies (Malvolti et al., 2010). As a consequence, genotypes with high oil contents also show high concentrations of $\gamma$-tocopherol and of linoleic and linolenic acids. Thus, the amount of oil content could be a reliable index for the amount of PUFAs in walnut oil, and consequently a reduction in time and cost of evaluating walnut oil at large scale.

The tocopherol concentration in walnuts is affected by climatic conditions (Martinez et al., 2006; Amaral et al., 2005) and geographical origin (Amaral et al., 2005). The effect of year was statistically significant for all tocopherol homologues (Table 4). The mean value of all tocopherol homologues was higher in 2009 than in 2010 (Table 3). Tocopherol levels increase in response to a variety of abiotic stresses, considered as evidence of its protective role (Munné-Bosch and Alegre, 2002). The climatic conditions of the year, mainly temperature, affect the concentration of the different tocopherol homologhes in several nut crops (Maranz and Wiesman, 2004), indicating that these components depend on the temperature and the occurrence of drought during fruit ripening. Since heat and drought stresses were higher in the 2009 fruit growing season than in 2010 (data not shown), they could increase the concentration of all tocopherol homologues in these non-irrigated genotypes. The year $\times$ genotype interaction for all tocopherol homologues (Table 4) indicated a different genotype behavior in relation to the climatic conditions, as already pointed out (Martinez et al., 2006). The genotypes Asni-3, Asni-4 and Asni-5 showed high and consistent values for $\gamma$-tocopherol and oil contents in both years. Taking into account the information on the protective function of $\gamma$-tocopherol (Verardo et al.,

TABLE 3. Tocopherol concentration in the kernel oil of Moroccan walnut seedlings over two consecutive years

\begin{tabular}{|c|c|c|c|c|c|c|}
\hline \multirow[b]{2}{*}{ Genotype } & \multicolumn{2}{|c|}{$\delta$-Tocopherol (mg $\mathrm{kg}^{-1}$ oil) } & \multicolumn{2}{|c|}{$\gamma$-Tocopherol $\left(\mathrm{mg} \cdot \mathrm{kg}^{-1}\right.$ oil $)$} & \multicolumn{2}{|c|}{$\alpha$-Tocopherol (mg $\cdot \mathrm{kg}^{-1}$ oil) } \\
\hline & 2009 & 2010 & 2009 & 2010 & 2009 & 2010 \\
\hline Asni-1 & $32.12 \pm 2.03$ & $23.30 \pm 1.64$ & $238.49 \pm 6.93$ & $207.49 \pm 5.32$ & $21.39 \pm 1.42$ & $8.70 \pm 0.87$ \\
\hline Asni-2 & $52.12 \pm 0.24$ & $35.12 \pm 0.13$ & $244.07 \pm 4.84$ & $205.79 \pm 3.42$ & $14.16 \pm 1.74$ & $13.55 \pm 1.24$ \\
\hline Asni-3 & $37.11 \pm 0.92$ & $49.74 \pm 0.63$ & $228.09 \pm 1.94$ & $234.59 \pm 2.41$ & $11.10 \pm 1.23$ & $10.49 \pm 2.41$ \\
\hline Asni-4 & $19.34 \pm 1.32$ & $31.63 \pm 1.08$ & $218.75 \pm 5.68$ & $218.50 \pm 7.32$ & $14.35 \pm 0.91$ & $19.09 \pm 1.08$ \\
\hline Asni-5 & $43.33 \pm 0.98$ & $25.51 \pm 3.25$ & $264.34 \pm 14.32$ & $262.53 \pm 11.2$ & $15.52 \pm 1.77$ & $12.05 \pm 1.52$ \\
\hline Asni-6 & $29.27 \pm 1.24$ & $26.60 \pm 1.34$ & $234.93 \pm 7.36$ & $184.36 \pm 3.78$ & $11.45 \pm 1.15$ & $15.13 \pm 0.52$ \\
\hline Asni-7 & $24.41 \pm 2.42$ & $26.47 \pm 1.75$ & $240.56 \pm 12.35$ & $162.20 \pm 20.54$ & $18.83 \pm 0.47$ & $13.07 \pm 0.33$ \\
\hline Asni-8 & $41.20 \pm 3.54$ & $29.30 \pm 1.22$ & $273.91 \pm 2.75$ & $174.32 \pm 4.32$ & $19.96 \pm 1.33$ & $17.15 \pm 2.01$ \\
\hline Asni-9 & $54.09 \pm 4.35$ & $31.98 \pm 3.57$ & $212.87 \pm 11.23$ & $182.75 \pm 13.47$ & $15.10 \pm 2.12$ & $13.18 \pm 0.89$ \\
\hline Asni-10 & $28.34 \pm 1.68$ & $23.76 \pm 2.66$ & $212.16 \pm 7.35$ & $201.48 \pm 9.24$ & $17.55 \pm 1.21$ & $16.60 \pm 0.94$ \\
\hline Means & $37.01 \pm 5.95$ & $31.07 \pm 12.08$ & $239.56 \pm 21.42$ & $203.62 \pm 15.08$ & $15.06 \pm 3.08$ & $13.60 \pm 5.95$ \\
\hline
\end{tabular}


TABLE 4. Analyses of variance for the three main tocopherol homologues of Moroccan walnut seedlings

\begin{tabular}{|c|c|c|c|c|}
\hline Source of variation & df & Mean square $^{a}$ & $F$-test & $p$-value \\
\hline \multicolumn{5}{|l|}{$\alpha$-Tocopherol } \\
\hline Genotype & 9 & $93.00 * * *$ & 98.95 & $<.0001$ \\
\hline Year & 1 & $173.60 * * *$ & 184.70 & $<.0001$ \\
\hline Year $\times$ Genotype & 9 & $44.33 * * *$ & 47.16 & $<.0001$ \\
\hline Error & 40 & 0.94 & & \\
\hline \multicolumn{5}{|l|}{$\gamma$-Tocopherol } \\
\hline Genotype & 9 & $937.35^{* * *}$ & 7.97 & $<.0001$ \\
\hline Year & 1 & $31805.81 * * *$ & 270.33 & $<.0001$ \\
\hline Year $\times$ Genotype & 9 & $762.07 * * *$ & 6.48 & $<.0001$ \\
\hline Error & 40 & 117.66 & & \\
\hline \multicolumn{5}{|l|}{$\delta$-Tocopherol } \\
\hline Genotype & 9 & $343.54 * * *$ & 113.33 & $<.0001$ \\
\hline Year & 1 & $8010.85^{* * *}$ & 2642.65 & $<.0001$ \\
\hline Year $\times$ Genotype & 9 & $227.32 * * *$ & 74.99 & $<.0001$ \\
\hline Error & 40 & 3.03 & & \\
\hline
\end{tabular}

$\mathrm{a} * * *$ : significant at $\mathrm{P}<0.001$.

2009) and the relevance of high lipid contents as a source of carbon and energy during germination and seedling growth (Chenevard et al., 1994), these genotypes could be considered as a seed source for walnut propagation in the high Atlas Mountains in Morocco to recover from forest degradation, since the choice of the seed source is considered crucial for the success of future plantings in the silvicultural management (Hemery, 2008; Callaham, 1994).

\section{CONCLUSIONS}

The present results are the first report on the chemical composition of the walnuts from the high Atlas Mountains in Morocco. The oil from their kernels presents medium to high oil content and concentration of PUFAs and of tocopherol, mainly of linoleic and linolenic acids, and of $\gamma$ - and $\delta$-tocopherols. This composition is similar to that of different commercial walnut cultivars. Thus, this oil may be considered as a nutraceutical oil and a good source of vitamin $\mathrm{E}$ for the human diet. These findings confirm the genotype and the year effects on the composition of the walnut oil, but the genotype characteristics are determinant in the year-to-year stability of this composition. Some genotypes (Asni-3, Asni-4 and Asni-5) showed high oil contents and consistently high values of $\gamma$-tocopherol. The introduction of these genotypes as new cultivars by vegetative propagation may result in a quality increase in the walnuts from the high Atlas Mountains of Morocco. In addition, these genotypes could be used as a seed source for walnut propagation in the same region, since the choice of the seed source is considered crucial for the success of future plantings in the silvicultural management.

\section{ACKNOWLEDGMENTS}

This research was funded by the grants of "Healthy Food for life" program Marie Curie IRSES, and the Research Group A12 of Aragón.

\section{REFERENCES}

Abbey M, Noaks M, Belling GB, Nestel PJ. 1994. Partial replacement of saturated fatty acids with almonds or walnuts lowers total plasma cholesterol and low-density-lipoprotein cholesterol. Amer. J. Clin. Nutr. 59, 995-999.

Amaral JS, Alves RM, Seabra RM, Oliveira BPP. 2005. Vitamin E composition of walnuts (Juglansregia L.): A 3-year comparative study of different cultivars. J. Agric. Food Chem. 53, 5467-5472. http://dx.doi.org/10.1021/jf050342u.

Amaral JS, Casal S, Pereira JA, Seabra RM, Oliveira BPP. 2003. Determination of sterol and fatty acid compositions, oxidative stability, and nutritional value of six walnut (Juglansregia L.) cultivars grown in Portugal. J. Agric. Food Chem 51, 7698-7702. http://dx.doi.org/10.1021/jf030451d.

AOAC. 1995. Association of Official Analytical Chemists. Official Methods of Analysis $16^{\text {th }}$ ed. Horwitz William: Washington DC.

AOCS. 1973. Method Ce 2-66. In: Official and Tentative Methods of the American Oil Chemist's Society, $3^{\text {rd }}$ Ed., Champaigne, IL.

Bada JC, León-Camacho M, Prieto M, Pocovi P, Alonso L. 2010. Characterization of walnut oils (Juglansregia L.) from Asturias, Spain. J. Am. Oil Chem. Soc. 87, 1469-1474. http://dx.doi.org/10.1007/s11746-010-1629-3.

Callaham RZ. 1994. Provenance research: investigation of genetic diversity associated with geography. Unasylva 18, $40-50$.

Chenevard D, Frossard JS, Lacointe A. 1994. Lipid utilisation and carbohydrate repartition during germination of English walnut (Juglansregia). Ann. Forest Sci. 51, 373-379. http://dx.doi.org/10.1051/forest:19940403.

Crews C, Hough P, Godward J, Brereton P, Lees M, Guiet S, Winkelmann W. 2005. Study of the main constituents of some authentic walnut oils. J. Agric. Food Chem. 53, 4853-4860. http://dx.doi.org/10.1021/jf0478354.

Dandekar AM, Leslie CA, McGranahan GH. 2005. Juglansregia walnut. In: Litz RE (Ed.) Biotechnology of Fruit and Nut Crops, CABI Publ., Oxfordshire, UK, 307-323. http:// dx.doi.org/10.1007/978-1-4419-0763-9 22.

Germain E. 1992. Le noyer. In: Gallais A, Bannerot H (Eds.) Amélioration des espèces végétales cultivées: objectifs et critères de sélection, INRA, Paris, 620-632.

Hemery GE. 2008. Forest management and silvicultural responses to projected impacts on European broadleaved trees and forest. Int. Forest. Rev. 10, 591-607. http://dx.doi. org/10.1505/ifor.10.4.591.

Jensen PN, Sørensen G, Engelsen SB, Bertelsen G. 2001. Evaluation of quality changes in walnut kernels (Juglansregia L.) by Vis/ NIR spectroscopy. J. Agric. Food Chem. 49, 5790-5796. http://dx.doi.org/10.1021/jf010509t

Lansari A, El Hassani A, Nabil D, Germain E. 2001. Preliminary results on walnut germplasm in Morocco. Acta Hortic. 544, 27-35.

Leslie CA, McGranahan GH. 1998. The origin of the walnut. In: Ramos DE (Ed.) Walnut Production Manual, Univ. California, Division of Agriculture and Natural Resources. Publ. 3373,3-7.

López-Ortiz C, Prats-Moya MS, Sanahuja S, Maestre-Pérez AB, Grané-Teruel N, Martín-Carratalá ML. 2008. Comparative study of tocopherol homologue content in four almond oil cultivars during two consecutive years. J. Food Comp. Anal. 21, 144-151. http://dx.doi.org/10.1016/j.jfca.2007.09.004. 
Malvolti ME, Pollegioni P, Mapelli S, Cannata F. 2010. Research of Juglansregia provenances by molecular, morphological and biochemical markers: a case study in Italy. Biorem. Biodiv. Bioavail. 4, 84-92.

Maranz S, Wiesman Z. 2004. Influence of climate on the tocopherol content of shea butter. J. Agric. Food Chem. 52, 2934-2937. http://dx.doi.org/10.1021/jf035194r.

Martinez ML, Maestri DM. 2008. Oil chemical variation in walnut (Juglansregia L.) genotypes grown in Argentina. Eur. J. Lipid Sci. Technol. 110, 1183-1189. http://dx.doi. org/10.1002/ejlt.200800121.

Martinez ML, Miguel AM, Maestri DM. 2006. Varietal and crop year effects on lipid composition of walnut (Juglansregia) genotypes. J. Am. Oil Chem. Soc. 83, 791-796. http:// dx.doi.org/10.1007/s11746-006-5016-z.

Mensink RP, Katan MB. 1989. Effect of a diet enriched with monounsaturated or polyunsaturated fatty acid on the levels of low-density and high-density lipoprotein cholesterol in healthy women and men. N. Eng. J. Med. 321, 436-441. http://dx.doi.org/10.1056/NEJM198908173210705.

Munné-Bosch S, Alegre L. 2002. The function of tocopherols and tocotrienols in plants. Crit. Rev. Plant Sci. 21, 31-57. http://dx.doi.org/10.1080/0735-260291044179.

Naito Y, Shimozawa M, Kuroda M, Nakabe N, Manabe H, Katada K, Kokura S, Ichokawa H, Yosida N, Noguchi N, Yoshikawa T. 2005. Tocotrienols reduce 25-hydroxycholesterol induced monocyte-endothelial cell interaction by inhibiting the surface expression of adhesion molecules. Atherosclerosis 180, 19-25. http://dx.doi.org/10.1016/j. atherosclerosis.2004.11.017

Reische DW, Lillard DA, Eitenmiller RR. 1998. Antioxidants. In: Akoh CC, Min DB (Eds.) Food Lipids. Chemistry, Nutrition, and Biotechnology. Dekker: New York, 423-448.

Rennie BD, Tanner JW. 1989. Fatty acid composition of oil from soybean seeds grown at extreme temperature. $J . A m$. Oil Chem. Soc. 66, 1622-1624. http://dx.doi.org/10.1007/ BF02636189.

SAS Institute, 2000. SAS User's Guide. SAS Inst., Cary, NC, USA

Savage GP, Dutta PC, McNeil DL. 1999. Fatty acid and tocopherol contents and oxidative stability of walnut oils. $J$. Am. Oil Chem. Soc. 7, 1059-1063.

Verardo V, Bendini A, Cerretani L, Malaguti D, Cozzolino E, Caboni MF. 2009. Cappillary gas chromatography analysis of lipid composition and evaluation of phenolic compound by micellar electrokinetic chromatography in Italian walnut (Juglansregia L.): irrigation and fertilization influence. J. Food Qual. 32, 262-281. http://dx.doi. org/10.1111/j.1745-4557.2009.00249.x.

Verardo V, Riciputi Y, Sorrenti G, Ornaghi P, Marangoni B, Caboni MF. 2013. Effect of nitrogen fertilisation rates on the content of fatty acids, sterols, tocopherols and phenolic compounds, and on the oxidative stability of walnuts. LWT-Food Sci. Technol. 50, 732-738. 